\title{
THE ADVANTAGE OF BURYING THE COLD-JUNCTION OF A THERMOCOUPLE AS A MEANS OF MAINTAIN. ING IT AT A CONSTANT TEMPERATURE.
}

Mr. Robert S. Whipple, M.I.E.E. (Cambridge), read a paper entitled "The Advantage of Burying the Cold-junction of a Thermocouple as a Means of Maintaining it at a Constant Temperature."

In March, 1903, Professor Anthony Zeleny, of the University of Minnesota, Minneapolis, suggested the advisability of burying the coldjunction of a thermocouple circuit as a means of maintaining it at a constant temperature.*

Although thermocouples have been frequently buried for the purpose of measuring earth temperatures, yet they have not, as far as I know, been buried for the purpose of maintaining the cold-junction of a thermoelectric circuit at a constant temperature. In the research laboratory, where accuracy is aimed at, it is customary to immerse the coldjunction in melting ice. As it is generally difficult to maintain an ice vessel near a furnace, this necessitates the placing of the ice vessel some distance from the source of heat. In the laboratory, where the cost of the wires for the rare-metal thermocouples was not very serious and where the furnace employed was small, this was not a matter of great importance ; but in the works, where a large number of couples are used and where long lengths of leads are required, the employment of melting ice is impossible. The difficulty has been overcome to some extent by the use of thermos-flasks, and it is now no uncommon sight to see an installation of thermos-flasks mounted near the furnaces of a large works. In practice the flasks are filled with oil, in which the cold-junction of the thermocouple circuit, together with a mercury thermometer, are immersed, the thermometer being a ready means of showing the temperature of the oil. Experience shows that in the majority of cases the daily temperature range indicated by the mercury thermometer does not exceed $2^{\circ} \mathrm{C}$, although the daily temperature range of the air surrounding the flask may amount to $10^{\circ}$ or $15^{\circ} \mathrm{C}$.

The introduction of Peake's compensating leads $\nmid$ has rendered it possible to transfer the cold-junction of a platinum, platinum-rhodium or iridium couple to a considerable distance from the head of the pyrometer, so that the employment of a buried cold-junction with the raremetal couples is rendered commercially possible.

The high price of platinum and its alloys has compelled the use of base-metal thermocouples, and the reliability of some of the modern

* United States Patent Specification No. 721,770, March 3, 1903.

+ See British Patent Specification No. 370, 1900, and "Methods of Measuring Temperatures," by R. S. Whipple, Proc. Inst. Mech. Eng., 1913, p. 729. 


\section{ADVANTAGE OF BURYING THE COLD-JUNCTION}

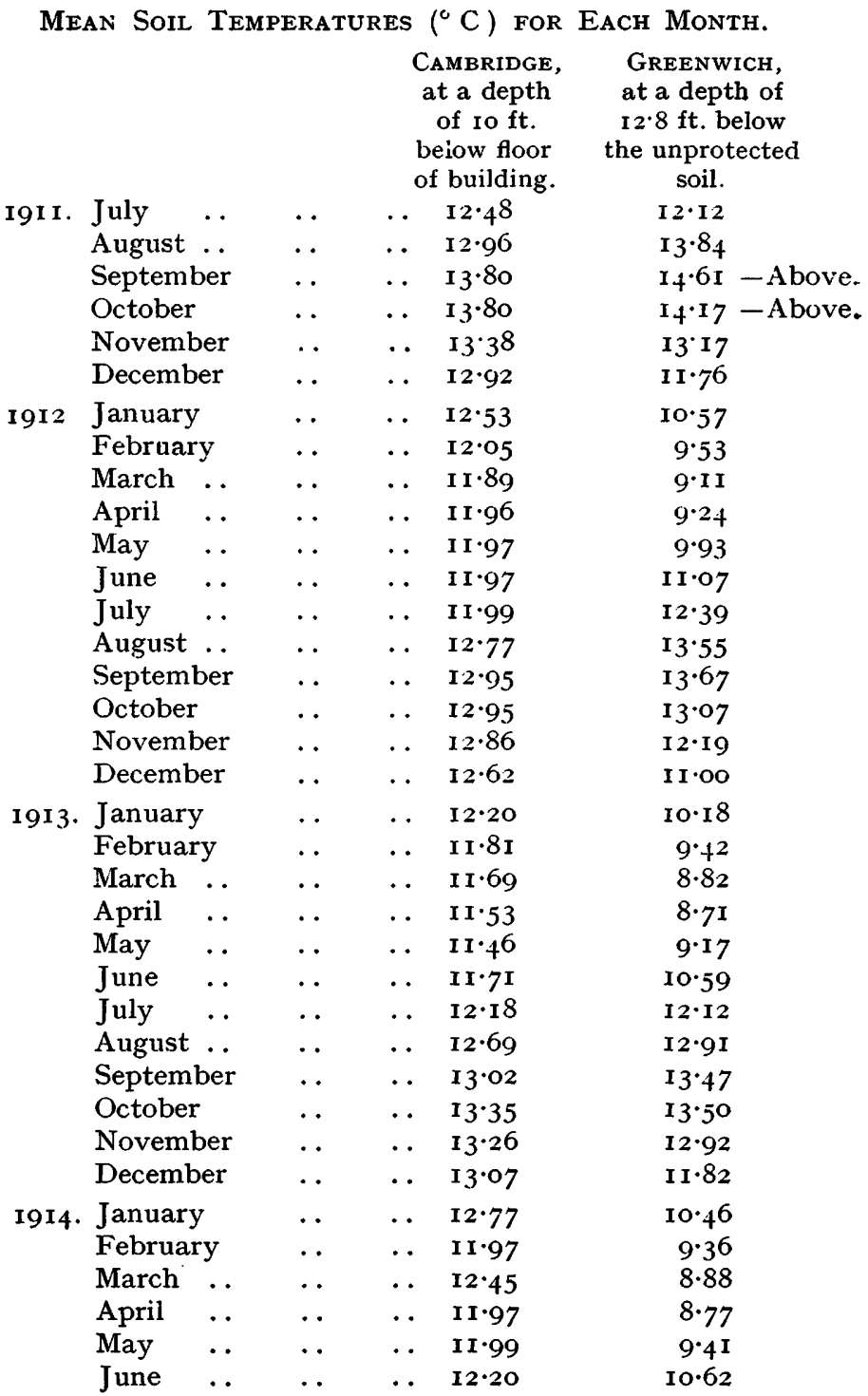

Maximum Temperatures $\left({ }^{\circ} \mathrm{C}\right.$.) in Each Year.

CAmbridge.

GREeNWICH

Temp. and Month.

July, I9II-June, I9I2 July, I9I2-June, I9I3 July, I9I3-June, I9I4
.. 13.80 Sept. \& Oct.

.. 12.95 Sept. \& Oct.

.. 13.35 October
Temp. and Month.

Above 14.6I Sept. 13.67 Sept. I3.50 Oct.

Minimum Temperatures $\left({ }^{\circ} \mathrm{C}\right.$.) in Each Year.

CAMBRIDGe.

Temp. and Month.

July, I9II-June, I9I2 July, 1912-June, 1913 July, I913-June, I914
.. II.89 March

.. 11.46 May

.. II·97 Feb. \& April
GREENWICH. Temp. and Month. 9. I I March 8.7I April 8.77 April 
elements, such as (1) nickel, nickel-chromium, (2) iron, nickel-copper, or (3) copper, nickel-copper, justifies the use of these elements to a high degree of accuracy. The materials mentioned are not expensive, and at once open up the possibility of burying as a means of maintaining the constancy of the temperature of the cold-junction.

In connection with some experimental work at the Cambridge Scientific Instrument Compary, it was desired to maintain a cold-junction at a constant temperature for a long period of time, and in July, I9II, one junction of a thermocouple was buried. The method of doing so may be of interest. A spot was. selected in the floor of the test-room,

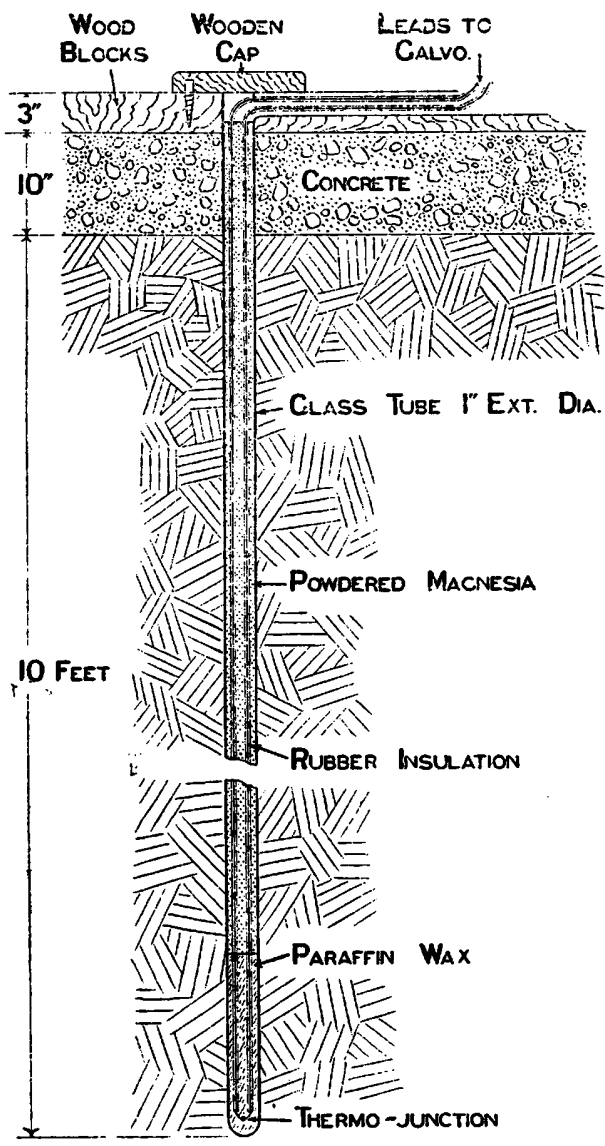

Fig. I.-Method of burying Thermocouple under Test-room Floor.

as near the centre as possible, and a hole driven through the floor to a depth of ro $\mathrm{ft}$. The ground having been made up about thirty years before, this was a comparatively easy matter. A copper-constantan (6o $\mathrm{Cu}-10 \mathrm{Ni}$ ) couple connected to copper leads was placed in a glass tube Io $\mathrm{ft}$. long, paraffin wax having been run into the bottom end of the tube for a depth of $\mathrm{I} 8$ in., and the remainder filled with powdered magnesid. The tube was then lowered into the hole, and, the ground being rnade-up soil, it immediately closed round the tube; indeed, some 


\section{ADVANTAGE OF BURYING THE COLD-JUNCTION}

little difficulty was experienced in putting the tube in, owing to the soil continually falling into the hole. The four wires projecting from the open end of the tube, those forming part of the thermocouple and the copper leads respectively, were taken to terminals in the form of two lead-covered cables. It is thus possible to connect any thermocouple having the same thermal constants to the buried one. The details of the arrangement are shown in Fig. I.

For a period extending over two years-July, I9II, to July, I913the electromotive force given by the couple was measured once a week by means of a potentiometer, the other junction of the circuit being

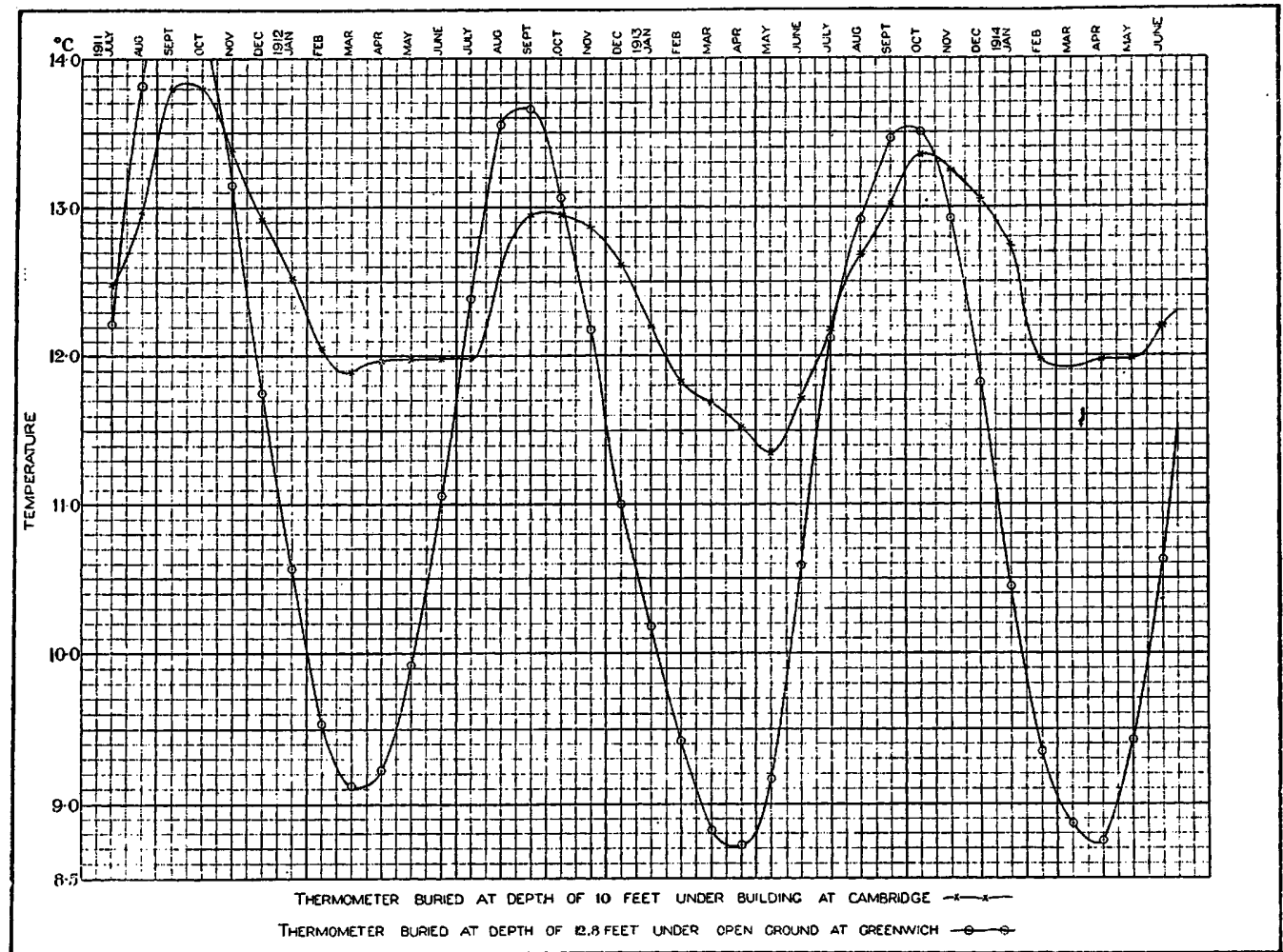

FIG. 2.-Mean Soil Temperatures, July I9II, to June, I9I4.

immersed in melting ice. During the period August, I9I3, to June, I9I4, the temperature of the couple was read at longer intervals of time, generally once a month. By the courtesy of Sir Frank Dyson, the Astronomer Royal, I am able to publish the monthly values given by a mercury-in-glass earth thermometer buried at a depth of $12.8 \mathrm{ft}$. at the Royal Observatory, Greenwich, over the same period. The values for the two sets of observations are shown in the table opposite, the values being shown graphically in Fig. 2.

It will be seen that the rise and fall in temperature at the autumnal and vernal equinoxes is clearly marked, even in the couple buried under the building. In the case under discussion, the tube in which the couple 
is buried is situated about ro $\mathrm{ft}$. from the exterior walls of the building. If, however, this distance could be made greater, it might, I think, be safely assumed that the temperature range would be less. It will be noticed that the times of maximum and minimum temperature agree with the Greenwich ones, but that, although the Greenwich thermometer is at a depth lower by $2.8 \mathrm{ft}$., yet the temperature range is approximately $3.5^{\circ} \mathrm{C}$. greater than that shown by the buried junction. This is not surprising when it is considered that in the one case the ground above the thermometer is exposed to the weather, and in the other it is protected by means of the building.

The following are the extreme ranges of temperature $\left({ }^{\circ} \mathrm{C}\right.$.) for the period under discussion--

\begin{tabular}{|c|c|c|c|c|c|c|c|}
\hline \multirow[b]{3}{*}{ July, I9I I-June, I912 } & \multicolumn{3}{|c|}{ CAMBRIDGE. } & \multicolumn{4}{|c|}{ GREENWICH. } \\
\hline & Max. & Min. & Range. & & Max. & Min. & ange. \\
\hline & . 13.80 & II. 89 & $I \cdot 91$ & Above & $14 \cdot 6 \mathrm{I}$ & $9 . \mathrm{II}$ & 5.50 \\
\hline July, I912-June, rgr3 & - $12 \cdot 95$ & $r 146$ & I. 49 & ", & 13.67 & $8 \cdot 7 \mathrm{r}$ & $4 \cdot 96$ \\
\hline July, I913-June, I914 & - $12 \cdot 35$ & I I.97 & $1 \cdot 38$ & " & $13^{\circ} 5^{\circ}$ & $8 \cdot 77$ & 473 \\
\hline
\end{tabular}

In a paper * recently published by Dr. Arthur Rambaut, the Director of the Radcliffe Observatory, Oxford, he discusses the results of temperatures obtained by underground thermometers at Oxford during the years - I899 to 1910, and shows that the maximum temperature range of the thermometer buried at a depth of $9 \mathrm{ft}$. $1 \times \frac{1}{2}$ in. below the surface is $6.88^{\circ} \mathrm{C}$., varying from $14.42^{\circ} \mathrm{C}$. in September, 1899 , to $7.54^{\circ} \mathrm{C}$. in March, 1909. From the mean monthly temperatures over the same period the extreme range is $5.15^{\circ} \mathrm{C}$., viz. from $13.26^{\circ} \mathrm{C}$. in September to $8.11^{\circ} \mathrm{C}$. in March. This value is almost identical with that obtained from the Greenwich thermometer buried at $12.8 \mathrm{ft}$. In the paper mentioned, Dr. Rambaut shows that at a depth of $66 \mathrm{ft}$. in Oxford gravel the temperature would remain sensibly constant throughout the year, i.e. the variation would not exceed $0^{\circ} \mathrm{or}^{\circ} \mathrm{C}$. He shows also that at $45 \mathrm{ft}$. the amplitude is $0 \cdot I^{\circ} \mathrm{C}$, so that an increase of $2 \mathrm{I} \mathrm{ft}$. in depth divides the amplitude of temperature range by ro. At Cambridge, therefore, if the law of diminution is the same, the range of $\mathrm{r} \cdot 6^{\circ} \mathrm{C}$. at ro $\mathrm{ft}$. would correspond with $0.16^{\circ} \mathrm{C}$. at $30 \mathrm{ft}$. and with $0.016^{\circ} \mathrm{C}$. at $5^{\circ} \mathrm{ft}$. Thus, to obtain almost absolute uniformity of temperature at Cambridge, it would be necessary to go down as low as $50 \mathrm{ft}$. In the case under discussion it is almost certain that, as this depth would be well below the river level, any deductions of this kind are unreliable. The phase agreement between Greenwich and Cambridge is rather remarkable when it is considered that the thermocouple is under a building, and can only be 3 or $4 \mathrm{ft}$. above the high-water level of the Cam.

The question of uniformity of underground temperatures is also complicated by rainfall. Professor H. L. Callendar has shown $\dagger$ in one of his papers on soil temperatures that rainfall is found to raise the value of the diffusivity of the soil very considerably. An abnormal rainfall

- "Underground Temperature at Oxford as determined by means of Five Platinum Resistance Thermometers, November, I898-October, I910," by A. A. Rambaut, Sc.D., F.R.S., Radcliffe Observiahons, vol. li.

$\dagger$ "Preliminary Results of Observations of Soil Temperatures with Electrical Resistance Thermometers, made at McDonald Physics Buildings, McGill University, Montreal," by H. L. Callendar, M.A., F.R.S., Transactions Royal Society of Canada, Section III, I895, P. I I. 


\section{$25^{8}$ ADVANTAGE OF BURYING THE, COLD-JUNC'TION}

may therefore cause a break in the constancy of temperature in a long series of readings. The larger the area of the floor of the building under which the buried couple is placed, the less will be the likelihood of rainfall affecting the constancy of the soil temperature below it. As the subject is of some interest, and the test-room at the works is now being increased in area, the opportunity is being taken to bury a thermocouple at a

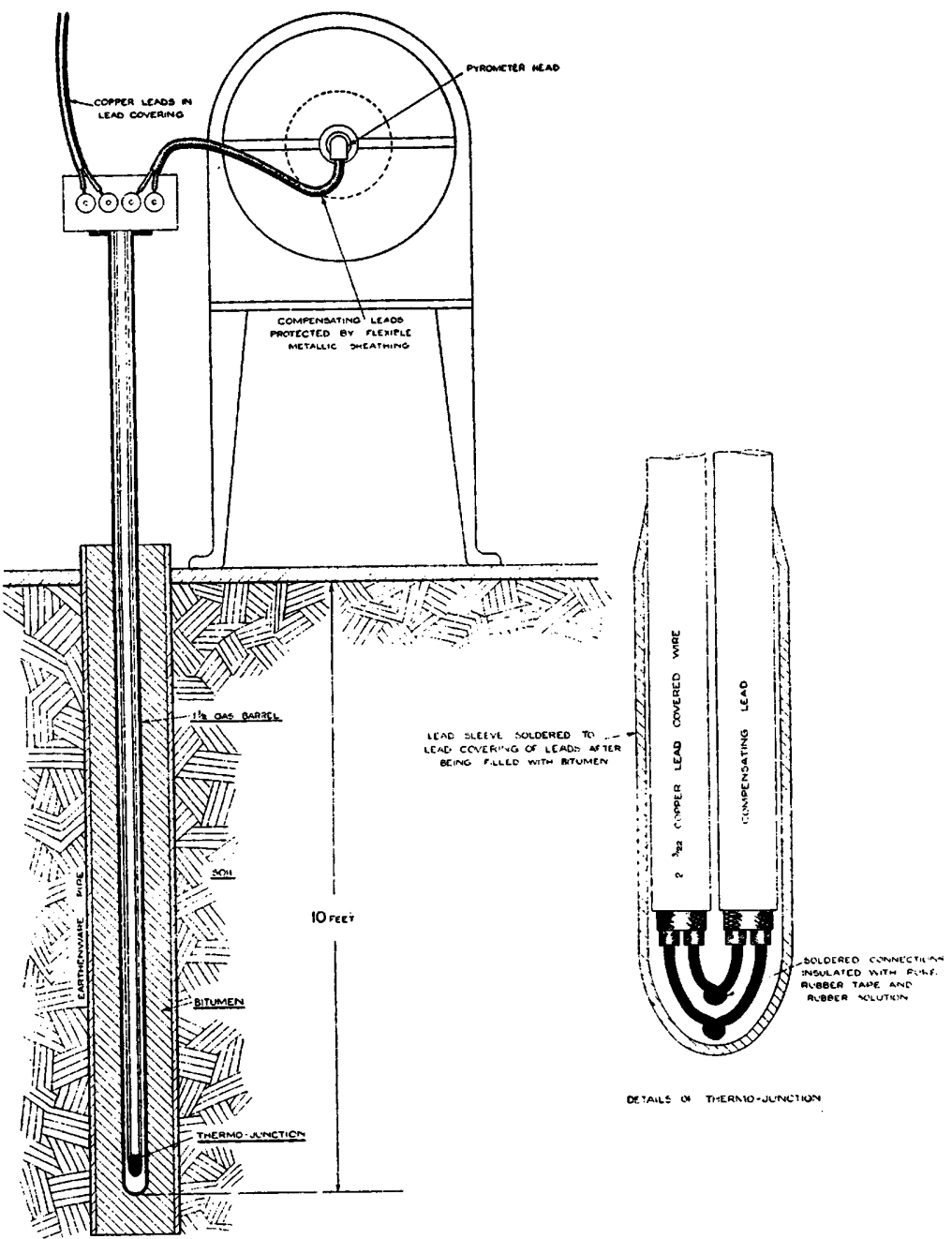

FIG. 3.-Method of burying Thermocouple in a Works.

depth of $20 \mathrm{ft}$. in the centre of what will be a much larger building. It is hoped that on some future occasion it will be possible to publish the results obtained.

The buried couple has proved successful in works practice, and it may be of some interest to show the method of burying the couple in one of the most successful installations. This method is illustrated diagrammatically in Fig. 3 . 


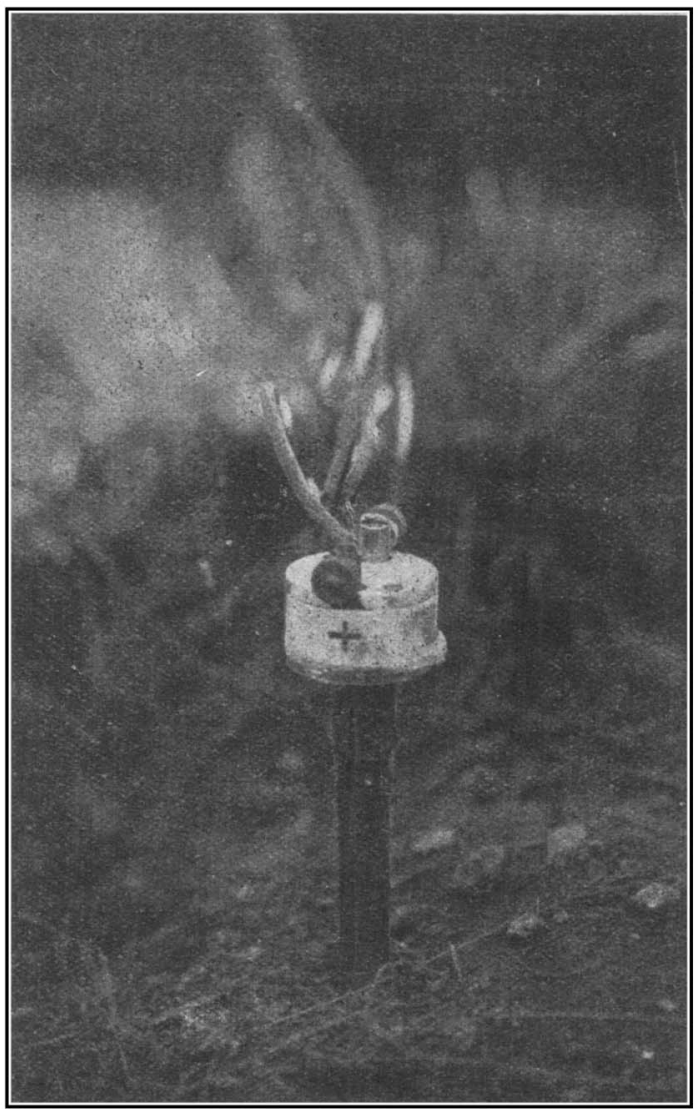

FIG. 4.-Tube containing the Cold-Junction as a Complete Unit driven into the Soil. 


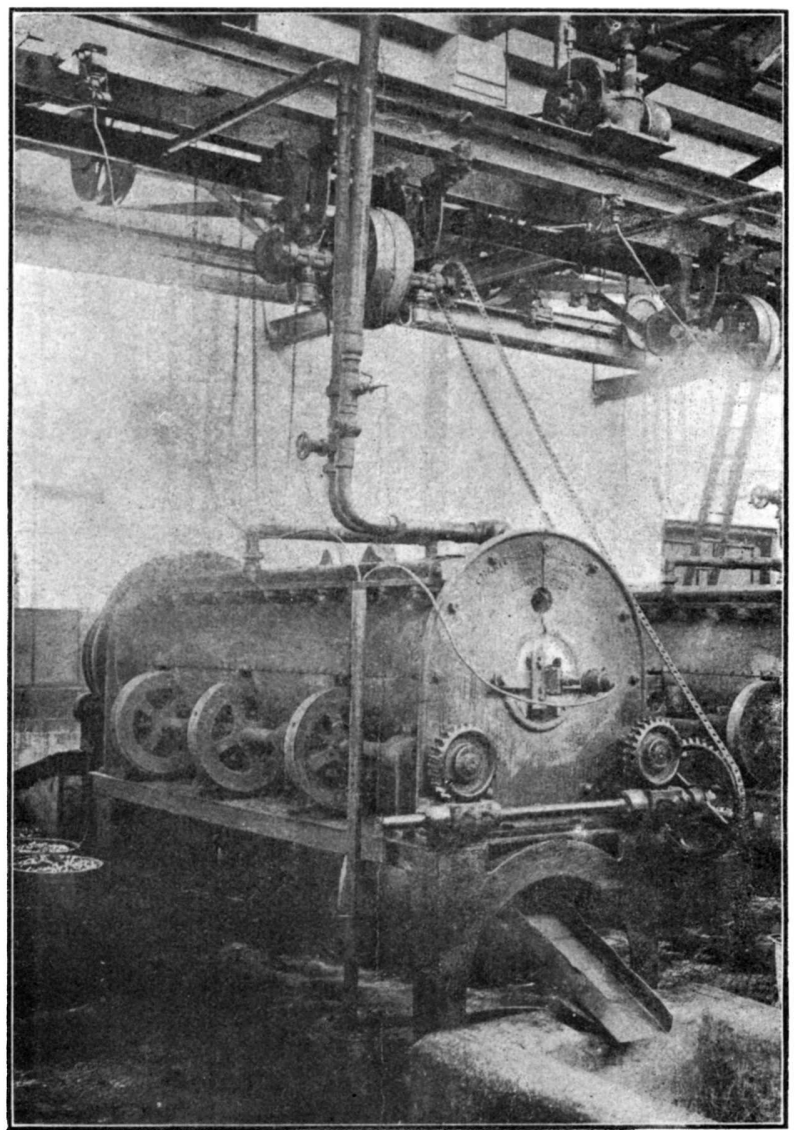

FIG. 5.-Buried Thermocouple in use in a Works. 
A steel tube closed at one end is buried in a small earthenware drainpipe to a depth of ro $\mathrm{ft}$., the space between the pipe and the tube being filled with bitumen. The copper lead wires are soldered to the compensating leads or other leads from the thermocouple, thus forming the cold-junction of the circuit. The joint is protected by an insulating material, such as bitumen, and a lead cap soldered to the outer lead sheathing protecting the thermometer wires. The two cables are then pushed to the bottom of the buried steel tube, the tube as far as possible being filled up with either hot bitumen or powdered magnesia. It is sometimes convenient to fit terminals on the head of the tube in which the cold-junction is buried, as shown in Fig. 3, or to construct the coldjunction arrangement in the form of a thermometer in which the protective sheath is driven into the ground. Such an arrangement is illustrated in Fig. 4, which I am enabled to reproduce by the courtesy of Mr. G. S. Heaven, of Messrs. White and Poppe. Buried junctions are being used by this firm in connection. with an installation of thermocouples measuring temperatures in an explosives factory. The arrangement shown in Fig. 5 is slightly different, in that the cables from the buried couple run direct to the couple placed in the furnace and to the temperature indicators without the interposition of any terminals. I am indebted to Mr. Frank and Mr. Kievits, of Messrs. Kynoch, Ltd., for their courtesy in allowing me to reproduce the method of burying the cold-junction of their thermocouples, as illustrated diagrammatically in Fig. 3. As showing the efficiency of the method in works practice, I may mention that Mr. Kievits informs me that over a period of six months it was found that the temperature of the soil did not vary by more than $\mathrm{I} \cdot 5^{\circ} \mathrm{C}$.

In conclusion, it may be stated ( $\mathrm{I}$ ) that the temperature of the coldjunction of a thermocouple system, if buried to a depth of ro $\mathrm{ft}$. beneath the floor of a fairly large building, will remain constant to within less than $2^{\circ} \mathrm{C}$. throughout the year; (2) that if Peake's compensating leads are used with platinum-platinum-rhodium couples there is no practical difficulty in using the buried cold-junction in a works. If base-metal couples are used, the problem is even less complicated, as simpler means of protecting the couple can be employed, the couple generally being more robust and the accuracy required being of a slightly lower order. 